\title{
Research on the Interactive Effect of the Free Trade Zone Framework and the Logistics Development of Chongqing Port
}

\author{
Yifei Gong, Feifei Shi \\ College of Economics and Management, Southwest University, Chongqing, China \\ Email: gyifei@swu.edu.cn
}

How to cite this paper: Gong, Y. F., \& Shi, F. F. (2020). Research on the Interactive Effect of the Free Trade Zone Framework and the Logistics Development of Chongqing Port. American Journal of Industrial and Business Management, 10, 935-943. https://doi.org/10.4236/ajibm.2020.105063

Received: April 15, 2020

Accepted: May 12, 2020

Published: May 15, 2020

Copyright $\odot 2020$ by author(s) and Scientific Research Publishing Inc. This work is licensed under the Creative Commons Attribution International License (CC BY 4.0).

http://creativecommons.org/licenses/by/4.0/

\begin{abstract}
This article briefly analyzes the development status of China (Chongqing) Pilot Free Trade Zone and Chongqing Port Logistics firstly, and then, the mechanism of interaction between the free trade zone economy and the logistics development of Chongqing Port is discussed from a qualitative perspective. Finally, according to the development status of Chongqing Port Logistics, some countermeasures are put forward to solve its development problems and realize the benign interaction between the free trade zone economy and Chongqing Port Logistics.
\end{abstract}

\section{Keywords}

Chongqing Free Trade Zone, Chongqing Port, Port Logistics, Interaction Effect

\section{(c) (i) Open Access}

\section{Introduction}

With the continuous development of economic globalization and regional economic integration, the logistics industry, as an important pillar industry of national economic development, has received the attention of all countries in the world and has become the focus of economic development strategies of them. As an important transit station for domestic and foreign trade, the port's continuous expansion of its logistics function has driven the development of economic and trade in various regions and further promoted the prosperity of local businesses. At the same time, the establishment of China's free trade zone not only provides new opportunities for China's economic development, but also makes ports become the core carrier of the free trade zone goods (Wang et al., 2018). Therefore, it is particularly important to study the interrelationship be- 
tween the port logistics and the free trade zone economy. However, most of the existing researches focus on the development of coastal port logistics, and there is not enough attention to how to develop inland port logistics under the framework of the free trade zone and promote the economic development of the free trade zone through the development of port logistics. Thus, based on the geographical advantages of Chongqing, this article explores the interactive effect between the economic development of the free trade zone and port logistics, and puts forward corresponding opinions for Chongqing Port to become an international logistics center.

\section{Current Situation Analysis}

\subsection{Development Status of China (Chongqing) Pilot Free Trade Zone}

As the only municipality in the central and western regions, Chongqing is not only an important fulcrum of the western development and an important hub for the interconnection of the Yangtze River Economic Belt and the "Belt and Road", but also is the basic premise of Chongqing's current development, including the construction of the free trade zone. At the same time, it has a good transportation foundation for the development of an international logistics center.

Chongqing Free Trade Zone was established on March 31, 2017. Its regional trade park has an implementation area of nearly 120 square kilometers, covering three areas: Liangjiang Area, Xiyong Area and Orchard Port Area. Among them, Liangjiang area is the core area, focusing on the development of high-end manufacturing, such as high-end equipment, biomedicine, and electronic chips, making advanced manufacturing bigger and stronger. Xiyong Area is the key area to create a demonstration zone for the transformation and upgrading of processing trade, focusing on the development of manufacturing industries such as intelligent equipment and electronic information, and optimizing the development mode of processing trade. The Orchard Port Area will focus on the establishment of a multimodal transport logistics transshipment center, develop international transfers, settling and distribution services, and explore innovative development of advanced manufacturing.

As the first batch of inland cities in China to set up a free trade zone, Chongqing draws on the experience of Shanghai, Guangdong, Tianjin and other free trade zones to implement an open and free policy. At the same time, the scope of the free trade zone mostly coincides with the China-Singapore (Chongqing) strategic interconnection project, both of them explore and innovate in trade liberalization, attract outstanding foreign-invested enterprises to settle in, distribute and circulate more international trade materials. Since the establishment of the free trade zone, Chongqing has achieved good results in the number of foreign direct investment projects, contract amounts and actual utilization (Table 1). 


\subsection{The Current Situation of Logistics Development in Chongqing Port}

Chongqing Port is the only national foreign trade port on the upper reaches of the Yangtze River and the main port for inland rivers in the country. It is also an important platform for the exchange of energy, raw materials and finished products in the western region and the distribution center for bulk cargo transportation in the southwest. Chongqing Port is mainly engaged in various comprehensive operating services such as passenger and freight transportation, logistics distribution, land and water transfer, port loading and unloading, warehousing services, etc. Chongqing Port currently has eight major port areas, 51 terminals and 874 berths. It mainly undertakes logistics transportation services such as dry bulk cargo, containers, hazardous chemicals, ro-ro cargo and ro-ro truck. In recent years, the functions of ports have gradually improved, and the logistics capabilities of foreign trade have also continued to increase (Luo et al., 2014; Yu et al., 2016). The specific performance is in the gradual improvement of the port's infrastructure and functions, and the steady improvement of international freight capacity. According to the statistics, the annual cargo throughout of Chongqing port has also been on the rise in recent years (Figure 1).

Although Chongqing port logistics has developed to some extent, there is still a big gap compared with advanced ports at home and abroad. At present, there

Table 1. Statistic of foreign direct investment in Chongqing.

\begin{tabular}{cccc}
\hline & $\begin{array}{c}\text { Number of Projects } \\
\text { Signed (unit) }\end{array}$ & $\begin{array}{c}\text { Contracted Foreign } \\
\text { Investment (USD 10,000) }\end{array}$ & $\begin{array}{c}\text { Foreign Capital Actually Utilized } \\
\text { (USD 10,000) }\end{array}$ \\
\hline 2018 & 232 & 907,480 & 325,030 \\
2017 & 238 & 383,207 & 222,004 \\
2016 & 224 & 401,022 & 262,630 \\
\hline
\end{tabular}

Data Source: Chongqing Statistical Yearbook 2019.

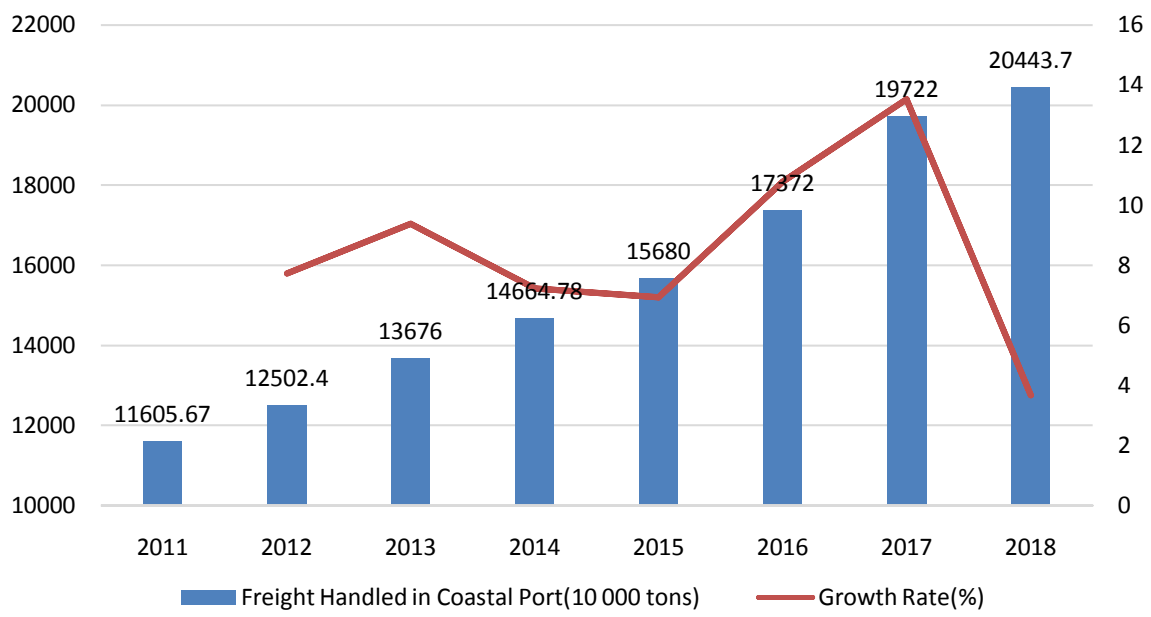

Figure 1. Freight handled in Chongqing port. Data Source: Chongqing Statistical Yearbook 2019. 
are problems such as insufficient function expansion, insufficient logistics management and technical personnel, low level of informatization, inadequate legal system, and low correlation with regional economic development, which are the major challenges faced by the logistics development of Chongqing Port.

Nowadays, the establishment of Chongqing Free Trade Zone has made the trade of goods and financial circulation more free and open. As a key node of trade in goods, port logistics has become the core carrier of goods transportation in the free trade zone. Therefore, thanks to Chongqing's geographical advantages, the establishment of a free trade zone, the support of the "Belt and Road" and the Western Development, Chongqing will surely create a new logistics model and promote the structural adjustment and upgrade of the development of port logistics.

\section{Coordinated Development Mechanism of Free Trade Zone Economy and Chongqing Port Logistics}

\subsection{The Relationship between the Economic Development of Chongqing Free Trade Zone and the Development of Chongqing Port Logistics}

With the acceleration of economic globalization and the continuous increase of foreign trade, China's port logistics can develop rapidly, and the development of port logistics will inevitably lead to the rapid development of port industries and the surrounding regional economy. There is a mechanism of interaction and coordinated development between port logistics and the urban economy and regional economy (Luo, 2010).

There is also a close relationship between the economy and the logistics industry in Chongqing Free Trade Zone. Chongqing Port Logistics promotes trade exchanges and cooperation between countries and regions, and promotes the commercial prosperity and development of Chongqing Free Trade Zone. In turn, the economic development of the free trade zone has also driven the logistics industry itself, and they have formed a virtuous circle to achieve common coordinated development and growth.

\subsection{The Mechanism of Free Trade Zone Economy's Effect on Chongqing Port Logistics Development}

The development of the free trade zone economy is the necessary premise and important guarantee for enhancing the sustainable development of Chongqing port logistics. With the rapid development of Chongqing Free Trade Zone and frequent connections with foreign economies, the scale of logistics demand for Chongqing Port is also increasing, which in turn promotes the expansion of port size, rich functions and industrial upgrading. As can be seen from the statistical data (Figure 2), Chongqing's import and export volume has been increasing year by year since 2016. After the establishment of the free trade zone in 2017, the import and export volume increased from 62.771 billion dollars in 2016 to 83.073 billion dollars in 2019 . The increase was nearly $32.30 \%$. The year-on-year 


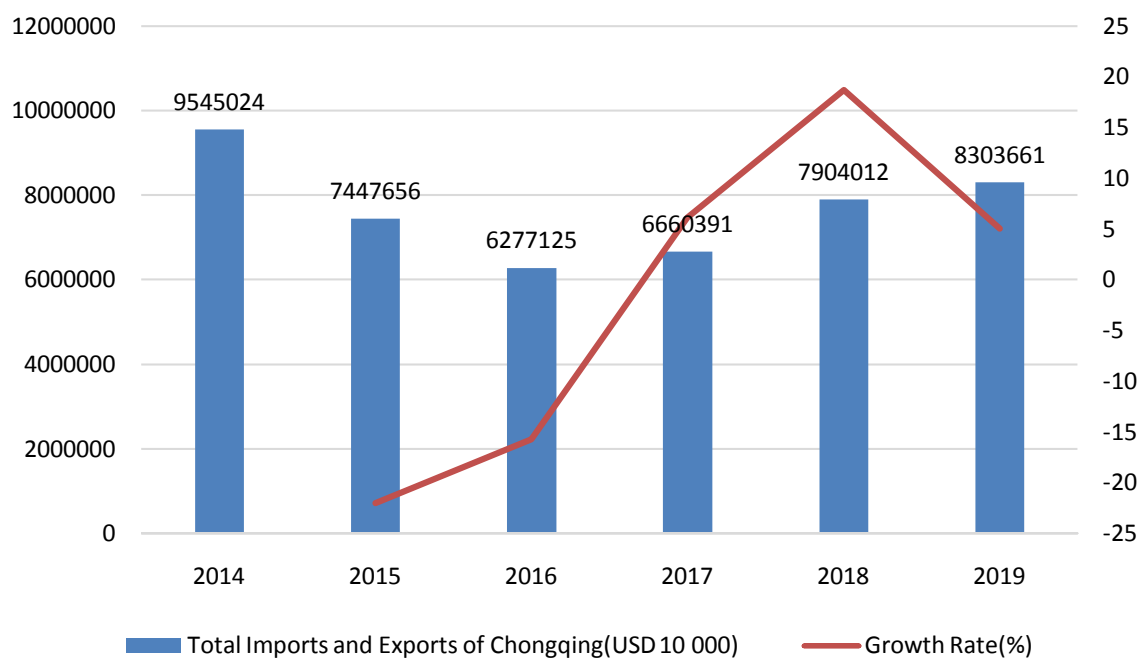

Figure 2. Total imports and exports of Chongqing. Data Source: Chongqing Statistical Yearbook 2019.

increase in trade volume has reduced the vacancy rate of various infrastructures of the port and improved the use efficiency. The establishment of a free trade zone can also bring benefits to land distribution centers, aviation logistics companies, ocean logistics companies and multimodal transport companies (Spencer, 2004), which effectively promote the development of Chongqing port logistics.

The economic development of the free trade zone can effectively improve the competitiveness of the port and increase the employment opportunities of the logistics industry. Due to the "siphon effect" (Fan, 2013), with the implementation of a series of favorable policies in the Chongqing Free Trade Zone, many foreign banks and well-known international companies have entered the mainland market one after another, bringing high-end industry and factor resource as well as corresponding capital flow, talent flow and information flow. As a key hub for global integrated transportation, the port will create more employment opportunities and improve the current shortage of logistics talents.

The main source of logistics for Chongqing Port Logistics comes from the economy of the local free trade zone. On the one hand, the free trade zone imports manufactured products and raw materials from overseas through ports for local production and processing. On the other hand, it sells products and processed materials through ports to enter overseas markets. Therefore, the economic development level, foreign trade situation, investment scale and other factors of the free trade zone will directly affect the throughout of Chongqing Port, thus affect the development of port logistics.

\subsection{The Effect Mechanism of Chongqing Logistics Port on the Economic Development of Free Trade Zone}

The economic benefits absorbed and produced by Chongqing ports directly promote the economic development of the free trade zone. The main manifesta- 
tion is that port logistics is a part of the national economy and regional economy. Like other industries, it also creates GDP and generates national income. According to data from the National Bureau of Statistics, in the past ten years, Chongqing's GDP has been rising continuously (Figure 3 ). The growth rate in the past two years has been close to $15 \%$. With such rapid growth in production and consumption, it would be impossible without a well-developed and port-centric logistics system to back it up. As an important part of the economic development of the free trade zone, Chongqing Port carries the distribution and turnover of goods from the free trade zone, creates wealth value and promotes employment. In addition, the efficient operation of port logistics can ensure that the free trade zone can maximize its function and further enhance the comprehensive competitiveness and influence of the free trade zone.

Innovative Chongqing port logistics can effectively improve the cargo turnover rate and the optimized logistics system can also ensure the efficient operation of the free trade zone, providing protection for it to attract investment and allow more excellent enterprises to enter, which provide more high quality resources for Chongqing Free Trade Zone in the fierce market competition. Thereby, Chongqing port logistics can stimulate the overall local economic, which plays an important role in promoting the economic development of the free trade zone.

The industrial cluster formed by Chongqing Port stimulates the economic growth of the free trade zone. Promoted by the development of port logistics, the resources transfer to low-cost areas of the port and regional industries are continuously concentrated to form industrial clusters which is formed by individuals holding together to increase overall strength (Liu, 2015), which has an important contribution to the economic development of the free trade zone. Chongqing Port has been committed to building a first-class inland international logistics center, introducing strong capital and advanced management concepts,

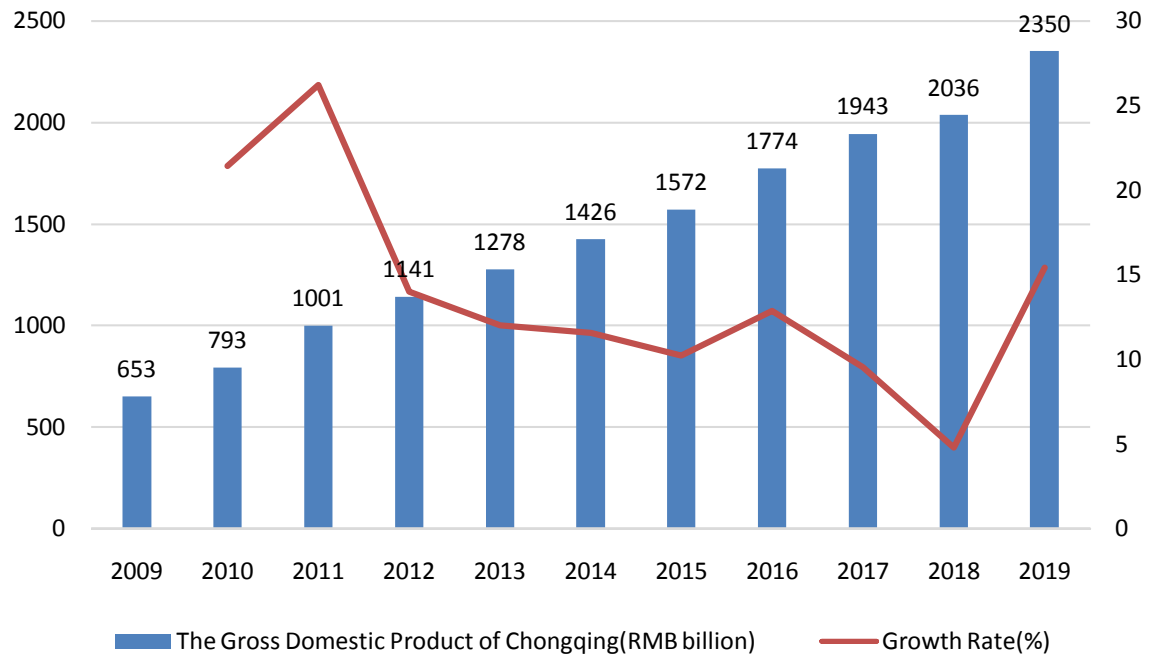

Figure 3. The Gross Domestic Product of Chongqing. Data Source: National Bureau of Statistics of China. 
and mutually benefiting the modern logistics industry cluster formed by the port, driving the economic development of the entire port and free trade zone.

The logistics development of Chongqing Port has a Matthew effect on the economic development of the free trade zone. The development of Chongqing Port Logistics has brought about the expansion of port size, increased freight volume and improved loading and unloading efficiency, and many cargoes in surrounding ports will be attracted to the port for transit. At the same time, the increase in transit cargo has stimulated the further development of the Chongqing Port Logistics, further promoted the development of port-related service industries, thus, formed the Matthew effect (Luo, 2010).

\section{Path Selection of Logistics Development of Chongqing Port under the Framework of Free Trade Zone}

\subsection{Attach Importance to Personnel Training and Provide Intellectual Support for Logistics Management}

The main dilemma of Chongqing Port's current development is the lack of management and technical logistics talents. Although the establishment of the Chongqing Free Trade Zone has brought many policies to promote the development of port logistics, the lack of logistics personnel has prevented many policies from implementing well. Therefore, under the framework of the free trade zone, the development of Chongqing Port Logistics should pay more attention to the education and training of logistics personnel, actively introduce high-quality logistics management talents, implement differentiated treatment, establish corresponding incentive mechanisms and retain the key management and technical talents.

\subsection{Expand Capital Investment and Actively Seek Trade Cooperation}

Thanks to Chongqing's geographical advantage and the "Belt and Road" policy advantage, the development of port logistics can achieve a win-win in terms of capital investment and trade cooperation. On the one hand, it can expand economic and trade investment, and actively apply for project funds for many financial institutions such as the Asian Investment Bank and the BRICS Open Bank, aimed at increasing the amount of capital invested in fixed assets in logistics. Which can improve the status of logistics supply capacity of Chongqing Port, enhance supply capacity and speed up logistics turnover to some extent. On the other hand, it is also possible to strengthen trade cooperation with countries along the "Belt and Road", driving more capital and talent flow for the free trade zone, and jointly explore a mutually beneficial and win-win logistics transaction mechanism to promote the development of Chongqing Port Logistics.

\subsection{Strengthen Government Guidance and Support, Improve Legal System Construction}

At present, the development of Chongqing Port Logistics still has problems such 
as unsound systems and relatively backward management and technology. Therefore, the government should actively adopt corresponding policy measures to encourage the development of port logistics and vigorously support and guide it. Specifically, it can be manifested in the relaxation of open measures for logistics supply enterprises and the appropriate reduction of prohibitions or restrictions in the negative list, attracting more logistics companies to settle in and keep up with the growing demand for logistics (Zhang, 2018). At the same time, strengthen the construction of the legal system and improve the legal environment of logistics development in the free trade zone to ensure that logistics enterprises compete with each other fairly under the legal constraints and policy support, and promote the healthy development of port logistics.

\subsection{Increase Infrastructure Construction and Improve Port Service Level}

In addition to talents, funds and policy support. The logistics infrastructure and technical services of Chongqing Port are also the core elements of its development. 1) Equipped with good hardware facilities, which are the basis of logistics operation, and the updating of logistics infrastructure should be synchronized with the development needs of logistics. 2) Establish a smooth traffic network. As a carrier of logistics, transportation is directly related to the benefits of port logistics. Optimizing the transportation network is one of the core elements for Chongqing Port to move towards the inland international logistics center. 3) Improve information construction. Speed up the establishment of a logistics information exchange system based on the Internet, tracking logistics information in a timely and efficient manner, and reducing logistics costs. 4) Improve port service level and awareness. The level of service is the main criterion for evaluating the satisfaction of a port's logistics quality. Through innovating the service features, it will bring good customer reputation to the port, which can increase its influence and form a competitive advantage.

\section{Conclusion}

Although the Chongqing Free Trade Zone has just started, the establishment of it has made Chongqing not only become an important engine for economic growth in the western region, playing a better pivotal role under the strategic landscape of the "Belt and Road", the Yangtze River Economic Belt and the Western Development, but also let the Chongqing Port Logistics usher in new development opportunities under the establishment of free trade zone. Chongqing Port Logistics has promoted trade exchanges and cooperation between countries and regions, and promoted the commercial prosperity and development of the Chongqing Free Trade Zone. The economic development of the Free Trade Zone is also a necessary prerequisite and important guarantee for the sustainable development of Chongqing Port Logistics. They complement each other and develop together. This article explores the interaction effect between the free trade zone economy and the Chongqing Port Logistics, which is helpful to ex- 
plore and construct a specific path for the development of Chongqing Port Logistics under the framework of the free trade zone, solving the current problems of port logistic, and better promote the connection and integration between Chongqing Port and the free trade zone, realizing the benign interaction between the free trade zone and the logistics development of Chongqing Port, and help Chongqing Port become a world-class inland logistics center.

\section{Acknowledgements}

Supported by 2016 Social Science Planning and Cultivation Project Research "on the Development Mode and Path of Inland International Logistics Center under the Framework of Chongqing Free Trade Zone (2016PY42)" and the Central University Basic Research Business Expense Project (SWU1909314).

\section{Conflicts of Interest}

The authors declare no conflicts of interest regarding the publication of this paper.

\section{References}

Fan, Y. B. (2013). The New Logistics Model Created by the Free Trade Zone: Interview with Zhang Jianping, Director of the International Economic Cooperation Office of the Foreign Economic Research Institute of the National Development and Reform Commission. Logistics and Procurement in China, No. 19, 34-35.

Liu, W. (2015). Research on the Development Strategy of Weihai Port Logistics under the Background of China-Korea Free Trade Zone. MSC Thesis, Dalian: Dalian Maritime University.

Luo, K., Xu, P., Liu, X. L., \& Ma, B. (2014). Analysis of Typical Cases of Port Development in Western China under the Development Mode of Port Logistics Hub-Taking Fangcheng Port and Chongqing Port as Examples. China Port, No. 2, 13-15.

Luo, Y. H. (2010). Research on the Mechanism and Strategy of Coordinated Development of Port Logistics and Regional Economy-Taking Maoming City as an Example. Guangxi Social Sciences, No. 5, 41-44.

Spencer, C. (2004). How the FTZ Program Can Improve Logistics. Journal of Commerce, $5,36-37$

Wang, R., Zhu, H. X., \& Wang, K. Z. (2018). Research on the Impact of System Innovation of Shanghai Free Trade Zone on Port Logistics. Economic Research Guide, No. 17, $116-117+122$.

Yu, R. H., Dang, Z. S., You, X. X., \& Jiang, C. Y. (2016). Eco-Environmental Problems and Countermeasures of Western Port Logistics Industry. Chongqing and World (Academic Edition), 33, 39-43.

Zhang, B. (2018). Research on the Logistics Development Model of Shanghai Free Trade Zone. MSC Thesis, Dalian: Dalian Maritime University. 